\title{
Conversion in Turkish: An overview
}

\section{Metin Bağrıaçık}

\section{Word Structure 11(2):148-174}

\begin{abstract}
This paper presents an overview of possible cases of conversion in Turkish. I argue that apparent cases of conversion between nouns and adjectives are cases of syntactic transposition, and apparent cases of conversion between nouns/adjectives and verbs are end products of phonological changes in the history of the language, which resulted in pairs of lexemes that are formally identical synchronically, but not historically. This does not mean that no cases of morphological conversion can be traced in the language. I will present two cases of secondary word-class conversion from derived, inflected and uninflected words to toponyms which might be taken as instances of morphological conversion or derivation by zero affixation.
\end{abstract}

\section{Keywords}

conversion, zero affixation, Turkish, toponym

\section{Introduction}

Various definitions of conversion have been proposed in the literature. According to one of the most widely adopted definitions, conversion is a synchronic morphological process whereby two formally (near-)identical lexemes which nevertheless belong to distinct lexical classes (as much as lexical classes can be differentiated) are linked to each other (adapted from Bauer \& Valera 2005: 8). This definition immediately raises at least two issues (for an overview, see Valera 2015): i) the criteria defining the limits of a lexical category; and ii) the exact machinery of the process that links the paired words 
to each other. In this paper, I will present an overview of possible cases of conversion in Turkish, and I will try to address these two problems to the extent permitted by the Turkish data.

Turkish has (at least) three domains which, at first glance, satisfy the definition of conversion given above. The first is the putative conversion between nouns and adjectives - categories which are not clearly distinguished morphologically in Turkish. A vast number of nouns can function as adjectives (and vice versa) without overt morphological affixation, which has been interpreted by certain scholars to indicate a lack of categorial distinction between adjectives and nouns in the language (for example, Swift 1963; Braun \& Haig 2000). I argue that lexical categories of nouns and adjectives in Turkish are formally distinct, even if members of one category can exhibit properties shared by the prototypical members of the other category. This, I will argue, is a case of reversible syntactic transposition, which is conditioned only contextually (after Kiefer's 2005 argument on similar cases in Hungarian), and it is not an instance of a morphological process of conversion, no matter how this process may be actualized.

The second domain involves apparent cases of conversion between nouns/adjectives and verbs. There are a number of morphologically identical verb roots and nouns/adjectives in Turkish, which raises the possibility that these pairs are related to each other through conversion. I show that these examples of apparent conversion are the result of certain phonological changes in the history of the language. Verbnoun/adjective pairs that in Old Turkic were related to each other through overt affixation have become identical in present-day Turkish due to the loss of (certain segments in) the affixes. In this domain as well, then, conversion is not the process responsible for the existence of formally identical pairs. 
The discussion of seemingly identical members in the lexical categories of adjectives, nouns and verbs in Turkish suggests that there are no cases of clear morphological conversion in this language. However, this conclusion seems to be refuted by two other sets of data. Adopting Inkelas \& Orgun's (2003) argument, I show that two sets of derived or non-derived words are converted into toponyms, and I argue that these two patterns can be claimed to involve zero affixes. The two zero affixes that are responsible for conversion are formally justified by the existence of their overt analogues. In effect, then, morphological conversion in Turkish can be claimed to exist, not among primary lexical categories of adjectives, nouns and verbs, but in a secondary word class, namely, the category of toponyms.

The paper is organized as follows: in $\S 2$, I present the first two domains of possible conversion in Turkish, namely between (a) nouns and adjectives, and (b) nouns/adjectives and verbs, and show that these cases do not instantiate morphological conversion. More specifically, in $\S 2.1$, I show that the putative conversion between nouns and adjectives (and vice versa) can best be characterized as reversible syntactic transposition. In $\S 2.2$, I argue that a diachronic analysis of pairs of lexemes belonging to the categories of nouns/adjectives and verbs, which at first seem to be linked to each other by means of conversion, shows that in reality the formal synchronic identity between the members of these pairs is the result of phonological changes that affected one of the members of these pairs. Next, $\S 3$ is devoted to the last domain of possible conversion, that is, conversion of (non-)derived words to toponyms. In $\S 3.1$ I provide background information on stress patterns in Turkish, which is crucial for the presentation and analysis of the data in $\$ 3.2$. $\$ 3.3$ provides information about another type of derivation of toponyms in Turkish, namely affixation via overt affixes. It is argued that conversion of (non-)derived words to toponyms should be analyzed as zero 
affixation. This argument and the analysis following it, as well as other ramifications of this analysis concerning the nature of conversion with respect to lexical categories, are given in $\S 3.4$, followed by a conclusion in $\S 4$.

\section{Primary word-class conversion in Turkish}

\subsection{Noun-to-adjective/adjective-to-noun conversion}

There is very little, if any, morphological difference between nouns and adjectives in Turkish. A large number of prototypical nouns can be used as adjectives and numerous prototypical adjectives can be used as nouns, for example, yiğit 'brave/brave man', erkek 'male/man', kadin 'female/woman', tel 'wiry/wire', çatal 'forked/fork' (Lewis 1967: 50). Moreover, derivational (1a-b) or inflectional (1c-d) suffixes typically attaching to one category also attach to almost all members of the other: ${ }^{1}$

(1)

Noun

Adjective

a. ögrenci-lik

çirkin-lik

student-DER

ugly-DER

'studenthood'

'ugliness'

b. hayvan-ca

özgür-ce

animal-DER

free-DER

'bestial(ly)'

'free(ly)'

c. çocuk-lar

yeni-ler

child-PL

new-PL

'children'

'new (ones)'

d. ev-e

sari-ya

house-DAT

yellow-DAT

'to the house'

'to the yellow (one)' 
Due to the difficulty in drawing a clear boundary between the two categories, various scholars have argued that (usually non-derived) lexemes which could be labeled as adjectives do not differ categorially from the so-called nouns (or vice-versa) in Turkish. These authors claim that lexical items belonging to adjectives and nouns in other languages form a single category in Turkish (Grønbech 1936: 3; Baskakov 1958: 60), which Swift (1963) calls the category of substantives. ${ }^{2}$ In a similar vein, Braun \& Haig (2000) argue that nouns and adjectives do not form polar categories based on typical properties of adjectives such as gradability (daha/en güzel 'more/(the) most beautiful') and ability to undergo partial reduplication (kap-kara [RED-black] 'pitch black'), or typical features of nouns such as modifiability (güzel ev 'beautiful house') or allowance of relational $-l I$ or privative $-s I z$ affixation (kar-li [snow-REL] 'snowy'; metelik-siz [penny-PRV] 'penniless'). Instead, there is a single category of nominals (or substantives à la Swift 1963), members of which stand on a continuum ranging from noun-like to adjective-like, depending on the number of adjective or noun characteristics they are associated with. Between the two ends, there are no-preference items, situated at various points on this continuum. Braun \& Haig (2000) further argue that identification of a lexical item as adjective or noun cannot be reduced to the existence or absence of one single formal property (the binary features of Chomsky 1970, or the unique structural features of Baker 2004) as there are intermediate points whose adjective-like or nounlike nature varies from one item to the other. Instead, they argue that each lexical item should be listed in the lexicon with its sui generis properties, locating that specific item on a specific point on the continuum.

In opposition to Grønbech (1936), Baskakov (1958), Swift (1963) and Braun \& Haig (2000), a number of authors maintain that adjectives and nouns do form distinct lexical categories in Turkish (Godel 1945; Johanson 1990; Kornfilt 1997, among 
others). Among these authors, Godel (1945) not only argues for the distinctness of adjectives and nouns but also postulates a systematic transpositional relationship between the two categories: "[t]he transposition of an adjective to noun or a noun to adjective is rather free, even for lexemes with [derivational] suffixes" (Godel 1945: 45; my translation, MB). Johanson (2006: 66-67), on the other hand, argues that, when nouns fill the modifier position in an NP (or, synchronically, a DP), they function as restrictive attributes, but they are not adjectivized. When a non-derived noun appears in a modifier position, there is a shift from its primary use as a noun to a secondary attributive use, without the use of zero-derivation (conversion) or a grammaticalization process. ${ }^{3}$ However, Johanson does not make explicit the status of adjectives that are used as nouns, but it seems that in this case as well, no zero-derivation or grammaticalization is involved. $^{4}$

The literature that defends the neutralization of adjective and noun categories in Turkish (see also Bhat 1994 for a cross-linguistic view) falls short of capturing those instances where nouns and adjectives differ starkly. To begin with, even studies that argue for a sharp distinction between adjectives and nouns cross-linguistically (for example, Baker 2004: 184) recognize the existence of "[...] kinds of words that are ambiguously nouns or adjectives cross-linguistically". According to Baker, these words mostly designate materials (iron, stone), sex (male) or nationality (Filipino). Interestingly, many of the lexical items which, according to Braun \& Haig (2000), are not located at the two poles of the continuum fall into one of the categories that are already shown to be ambiguous by Baker (2004). Therefore, in this case Turkish does not differ substantially from other languages.

Moreover, it is a fact that in Turkish as well, there are prototypical nouns (for example, ayakkabi 'shoe') and prototypical adjectives (for example, kaygan 'slippery'), 
which show contrasting properties: ayakkabi 'shoe' cannot be graded (*dahalen ayakkabi 'more/(the) most shoe'), a prototypical peculiarity of adjectives (Jackendoff 1997), nor can it undergo reduplication (*ap-ayakkabi [RED-shoe]). An adjective such as kaygan 'slippery' cannot readily undergo nominal derivation with the agentive $\{-C I\}$ (*kaygan-ci), nor does it admit nominal inflectional endings easily (??kaygan-a [slippery-DAT]). Locating such prototypical nouns and adjectives on opposite ends of a hypothetical continuum simply changes the terminology from nouns to noun-like and from adjectives to adjective-like.

Finally, there seem to be unambiguous adjectives which, nevertheless, do not show all the prototypical peculiarities of adjectives, for example, non-scalar, nonpredicative (operator) adjectives such as sözde 'alleged'. These adjectives cannot be graded or intensified by reduplication. This, however, does not entail that they are more noun-like, so the continuum approach does not apply to these cases. Overall, Turkish does not seem to constitute an exotic case when categories of nouns and adjectives are taken into consideration, and the existence of nouns and adjectives with distinct properties should be recognized in Turkish as well.

A logical question then emerges about the status of numerous no-preference elements in Turkish: are they outputs of a morphological process of conversion/zeroderivation or are they cases of syntactic transposition/re-categorization? According to Kastovsky (2005: 35, §2.4), for cases where an adjective is used as a noun (e.g., $u_{z u n}{ }^{\text {Adj/N }}$ 'tall/tall person/thing'), the term zero-derivation/conversion might not be suitable. Instead, he argues for German and English, these should be handled as instances of syntactic transposition (see also Manova \& Dressler 2005). According to Kastovsky, many of these instances can be handled with the stipulation of an elided head noun (or, in more synchronic terms, of a silent head à la Kayne 2005; 2015). 
Therefore, $u z u n^{\mathrm{Adj}}$ 'tall' can appear to surface as a noun, that is, $u z u n^{\mathrm{N}}$ 'tall' but only with the stipulation of an elided/silent head, that is, uzun $\varnothing^{\mathrm{N}} /\{$ PERSON/THING $\}$ 'tall (one/thing)'. This entails that what is observed is a syntactic, rather than a morphological phenomenon.

Although such an analysis may capture how prototypical adjectives can be used as nouns, it falls short of explaining how prototypical nouns can be used as modifiers, for example, çubuk kraker 'stick cracker'. In this case, it is clear that an elided/silenthead analysis would not work, and all that remains would be to postulate a NN compound analysis. However, it has been independently argued in Bağrıç̧ı \& Ralli (2013) that not all such concatenations in Turkish can be identified as compounds, and at least some should be recognized as noun phrases involving a prenominal adjectival modifier. Therefore, although the syntactic conversion analysis seems appealing, it should not be attributed to elision/silent heads. Instead, I argue, in line with Kiefer (2005) for similar cases in Hungarian, that the transposition between adjectives and nouns in Turkish is contextually determined. More particularly, when a noun is used as an adjective, an entity is replaced by a property or a set of properties of that entity, without a fundamental change in lexical category. This is captured by Kiefer (2005: 54) with the following generalization (slightly adapted):

If $\sigma P$ is a salient property or a set of salient properties associated with the entity $E$, then a noun referring to that $E$ can be transposed into an adjective expressing that particular $\sigma P$.

The ambiguous behavior of almost all nouns labeled as no-preference follows from Kiefer's generalization above: in a concatenation such as çubuk kraker 'stick cracker', for example, the noun çubuk seems to be transposed to an adjective based on its salient properties 'thin' and 'long'. This transposition also explains how, under appropriate 
circumstances, an item labeled as "adjective-like" by Braun \& Haig (2000) can be used as a noun without sharing morphological peculiarities of prototypical nouns. Kiefer (2005: 56) proposes the following generalization (slightly adapted):

If $\sigma P$ is a salient property or a set of salient properties of the entity $E$, then the adjective expressing $\sigma P$ can be used to denote $E$.

This generalization accounts for many no-preference elements that are originally adjectives (for example, $k \ddot{o r} r^{\mathrm{Adj} / \mathrm{N}}$ 'blind (one(s))', $\operatorname{sart}^{\mathrm{Adj} / \mathrm{N}}$ 'yellow (one(s))'). For Kiefer, contextually determined conversion is a morphological phenomenon. However, in Turkish, there is little evidence to support the view that the phenomenon is a morphological one. Transposed nouns that can be used attributively, such as ayakkabit 'shoe' in ayakkabi ev [shoe house] 'a house in the form of a shoe', resist various morphological or syntactic operations exclusive to adjectives. Among these are deadjectival adverbial suffixation $\{-C A\} \quad$ (*ayakkabi-ca [shoe-ADV]), partial reduplication (*ap-ayakkabi [RED-shoe]), or use of comparative and superlative particles $(*$ daha/en ayakkabi $[$ more/(the) most shoe]).

Therefore, unlike Kiefer (2005), I would like to suggest that this apparent change of category, which is contextually determined in Turkish, does not have enough morphological repercussions to be called a morphological phenomenon. The process, even if productive, does not yield a homogenous class of adjectives or nouns. In line with Marchand (1967: 16, 18-19; 1969: 360), I argue that these are cases of reversible syntactic transposition and not of zero affixation (see also Dokulil 1968a: 231; 1968b: 57). The transposed words only take on the syntactic behavior of the target word class; theydo not necessarily change lexical categories, nor do they undergo a morphological process that results in adjectives that behave in all ways similarly to prototypical members of the set of adjectives. Since such transposition is quite free in Turkish, in the 
rest of the paper adjectives and nouns will often appear together, and they will occasionally be referred to as "nominals" collectively.

\subsection{Noun/adjective-to-verb and verb-to-noun/adjective conversion}

Conversion of nouns/adjectives to verbs in Turkish is rather rare, if it exists at all. Examples of formally identical nominal-verb pairs from Lewis (1967: §20) and Kornfilt (1997: 453) are given in (2).

$\begin{array}{lll}\text { (2) Nominal } & \leftrightharpoons & \text { Verb } \\ \text { aci } & \leftrightharpoons & \text { aci- } \\ \text { 'pain' } & \text { 'hurt (intr.)' } \\ \text { boya } & \leftrightharpoons & \text { boya- } \\ \text { 'paint' } & \text { 'paint (tr.)' } \\ \text { kuru } & & \text { 'dry (intr.)' } \\ \text { 'dry' } & \leftrightharpoons & \text { ekşi- } \\ \text { ekşi } & & \text { 'go sour (intr.)' } \\ \text { 'sour' } & & \end{array}$

Even these few examples, however, cease to be genuine cases of conversion when investigated from a diachronic point of view. The Old Turkic counterparts of the nominal bases in (2) are in fact deverbal nominals derived with the addition of the derivational suffix $\{-(V) g\}$ (Tekin 1968: 111; Clauson 1972: xliv; Erdal 1991: 172-224 $\S 3.101 ; 2004: 153)$ :

$\begin{array}{lll}\text { (3) Nominal } & & \text { Verb } \\ \text { ači-g } & & \text { ači- } \\ \text { 'pain' } & \leftarrow & \text { 'hurt oneself' } \\ \text { bodo-g } & \text { bodo- } \\ \text { 'paint, henna' } & & \text { 'paint' }\end{array}$




$\begin{array}{lll}\text { kurl-g } & \leftarrow & \text { kurl- } \\ \text { 'dry' } & \leftarrow \text { 'be/become dry' } \\ \text { ekşi-g } & \text { *ekşi- } \\ \text { 'sour' } & \text { 'go sour, rot' }\end{array}$

$\{-(V) g\}$ was a common deverbal derivational suffix in Old Turkic (Erdal 2004: 153), which is retained in Standard Turkish as the derivational suffix $\{-I\}$ (for example, ver-i 'datum' $<$ ver- 'give' by analogy with Latin datum $<$ dare). ${ }^{7}$ What appears in (2) as synchronic conversion in Turkish, then, is only apparent and is due to the loss of final /g/ of the deverbal $\{-(V) g\}$ suffix in Standard Turkish. This case is similar to the apparent synchronic conversion between certain nouns and adjectives in English, such as stone, which is due to the loss of the adjectival -en suffix on the derived adjective stcenen $^{\text {Adj }}$ 'stone', which is itself derived from the noun $\operatorname{stan}^{\mathrm{N}}$ 'stone' (cf. Kim 2010: 23 , her (20)).

Other cases that are cited as examples of conversion in Standard Turkish (cf. Lewis 1967: 226, §20) also turn out to be results of phonological changes that took place in the history of the language:

(4)

$\begin{array}{lll}\text { Nominal } & \leftrightharpoons & \text { Verb } \\ \text { göç } & \text { göç- } \\ \text { 'migration' } & \text { 'migrate' } \\ \text { gerek } & \leftrightharpoons & \text { gerek- } \\ \text { 'necessary' } & \text { 'be necessary' } \\ \text { eski } & \leftrightharpoons & \text { eski- } \\ \text { 'old' } & & \text { 'become worn out' }\end{array}$

Göç/göç- 'migration/migrate' existed in Old Turkic as well, in the form köč 'migration, load' and köč- 'migrate'. However, Nişanyan (2016) analyzes the noun and the verb as 
two different forms derived from the same verbal stem köt- 'lift'. The nominal form, according to Nişanyan, is derived from the verb $k \ddot{o} t$ - with the deverbal nominal suffix $\{-$ $(V) \check{s}\}$, whereas the verbal form is derived with the co-functional/reciprocal suffix $\{-$ $(V) s\} .{ }^{8}$ Similarly, the pair gerek/gerek- 'necessary/be necessary' also existed in Old Turkic (cf. kergek, also kerek 'lacking, missing', kerek- 'feel the absence/deficiency of $\mathrm{X}^{\prime}$ ). Both forms are derivatives from the verbal base kerge- 'lack' by attachment of distinct suffixes. Nominal gerek carries the deverbal nominal suffix $\{-(V) k\}$, whereas verbal gerek- features the reflexive suffix $\{-(V) k\}$ (Nişanyan 2016). Finally, the counterpart eski/eski- 'old/become worn out' occurs in Old Turkic as eski 'old' and eskir- 'become worn out', which in turn is derived from the nominal base by suffixation of the denominal verbalizer $\{-(V) r\}$ (Erdal 1991: 499-507, §5.45). The form eski-, where the final $/ \mathrm{r} /$ is dropped, is observed in Standard Turkish and certain other varieties of Turkish. ${ }^{9}$

The discussion so far has revealed that noun/adjective-to-verb conversion (or vice versa) is rather rare (perhaps non-existent) in Turkish. This conclusion can be further supported from a diachronic perspective. It has been noted that "[in Old Turkic t]he identical nominal and verbal stems are extremely few [...]" (Tekin 1968: 103). The following two Old Turkic examples are often cited (Tekin 1968: 103; see also Erdal 2004: 228):

$\begin{array}{lll}\text { (5) Nominal } & \leftrightharpoons & \text { Verb } \\ a \check{c} & a \check{c}- \\ \text { 'hungry' } & \leftrightharpoons & \text { 'feel hungry' } \\ \text { qari } & & \text { qari- } \\ \text { 'old' } & & \text { 'grow old' }\end{array}$


Even these two cases, however, do not survive in Modern Standard Turkish as such. ${ }^{10}$ Neither of the two lexemes qari exist today with the same meaning, and while nominal $a c ̧$ 'hungry' is retained, the corresponding verb is now derived via the reflexive suffix $\{-$ $I k\}$ ( ac-ik- 'become hungry'). ${ }^{11}$

We may therefore conclude that noun/adjective-to-verb and verb-tonoun/adjective conversion does not seem to exist in Turkish. One possible reason for the extreme rarity of nominal-to-verb conversion is the existence of the highly productive and polysemous denominal verbal suffix $\{-l A\}$ (Lewis 1967: 226; Kornfilt 1997: 453; Göksel \& Kerslake 2005: 56), which attaches to both native (6a) and nonnative (that is, borrowed) (6b) nominal bases:

(6)

$$
\text { Verb Base }
$$

a. baş-la- $\quad$ baş

\begin{tabular}{llll} 
'start' & \multicolumn{1}{l}{ 'beginning' } & $(<$ OT baš $)$ \\
su-la- & su & \\
'water' & 'water' & $(<$ OT suv $)$ \\
yelpaze-le- & yelpaze & \\
'fan (with a hand fan)' & '(hand) fan' & (<OT yelpise $)$
\end{tabular}

b. Google-la- $\leftarrow \quad$ Eng. Google

'google'

rast-la- $\quad$ rast

'run across' 'coincidence' $\quad(<$ Far. rāst $)$

hak-la- $\quad \leftarrow \quad$ hak

'overcome' 'right, warrant' $\quad(<$ Ar. hakk $)$

örnek-le- $\quad \leftarrow \quad$ örnek

'exemplify' $\quad$ 'example' $\quad(<$ Arm. orinag $)$ 
The semantic relationship between the verbs derived with $\{-l A\}$ and the corresponding bases is not completely predictable:

(7)

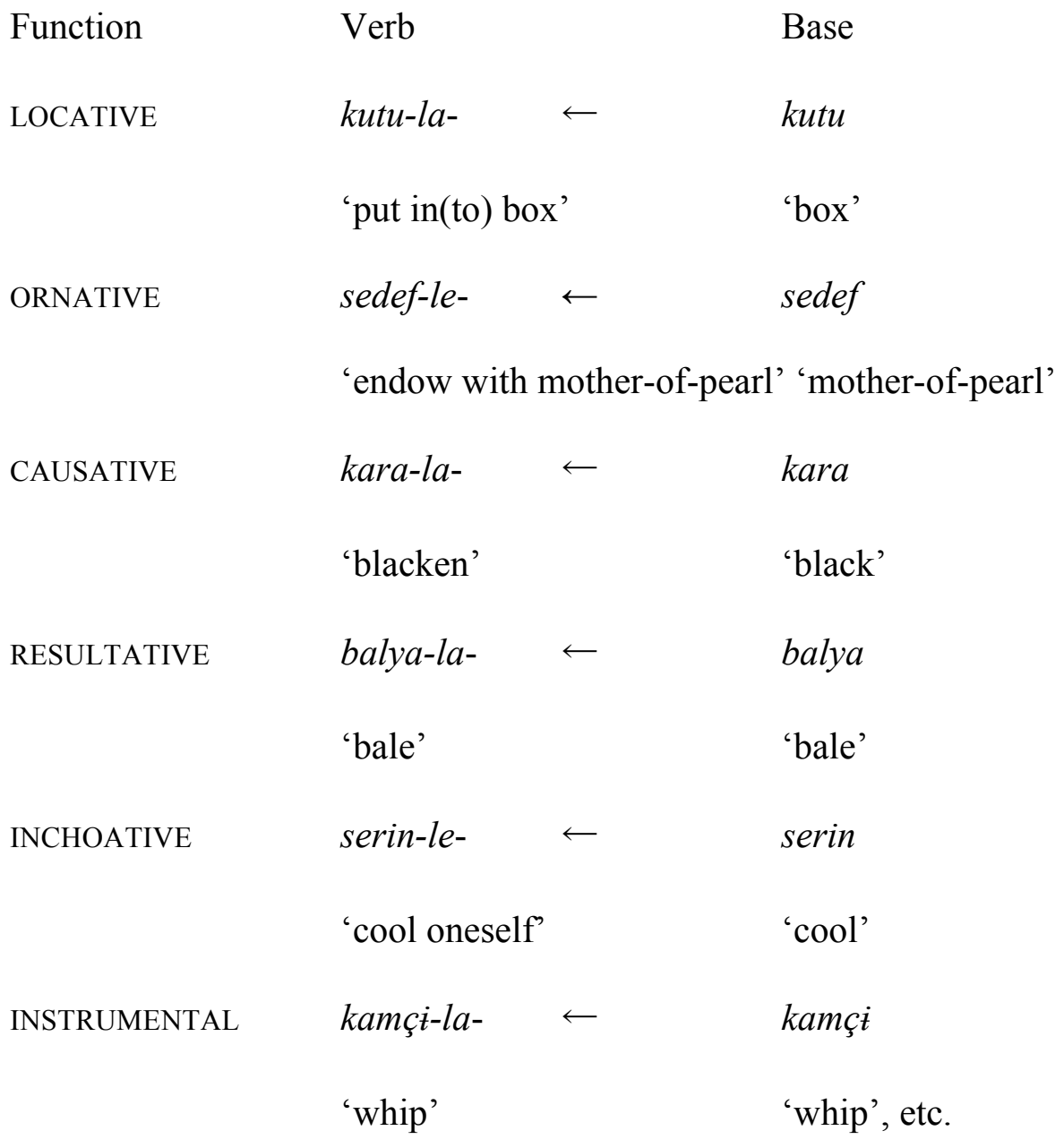

Moreover, $\{-l A\}$ can combine with the passive $\{-n\}$ or reciprocal $\{-s\}$ yielding the compound suffixes $\{-l A n\}$ or $\{-l A s ̧\}$ :

(8)
Verb
Base

$\begin{array}{lll}\begin{array}{l}\text { a. ayak-lan- } \\ \text { 'revolt' }\end{array} & < & \begin{array}{l}\text { ayak, *ayak-la- } \\ \text { 'foot' } \\ \text { heyecan-lan- } \\ \text { 'be excited' }\end{array} \\ \text { b. Avrupalt-laş- } & < & \text { heyecan, *heyecan-la- } \\ \text { 'be Europeanized' } & & \text { Avrupali, *Avrupali-la- } \\ \text { buhar-laş- } & < & \text { 'European' }\end{array}$


'evaporate' 'vapor'

The highly productive nature of $\{-l A\}$ (and compound suffixes which it takes part in) in Turkish has probably had a blocking effect on nominal-to-verb conversion.

The previous two sections presented an overview of possible cases of conversion between primary word classes of verbs, nouns and adjectives in Turkish. I argued in $\$ 2.1$ that apparent cases of conversion between nouns and adjectives (and vice-versa) are instances of reversible syntactic transposition rather than results of the morphological phenomenon of conversion. The transposed words behave like the members of the target word class without changing their lexical category. Moreover, I argued in $\S 2.2$ that almost all putative instances of conversion between nominals and verbs can be explained away as outcomes of certain diachronic phonological changes that have ultimately resulted in homonymous pairs. That means, then, that there are no clear cases of morphological conversion between primary word classes in Turkish. ${ }^{12}$ This, however, should not be taken to mean that morphological conversion is not available to Turkish as a word-formation process at all. In the next section, following Inkelas \& Orgun (2003), I will present instances of word-formation, specifically derivation of toponyms out of nominals, which can be analyzed by a zero-derivation analysis.

\section{Conversion to toponyms in Turkish}

In this section, I first present background information on stress in Turkish (§3.1), which is crucial for the discussion of conversion of (non-)derived words to toponyms (§3.2). The existence of certain overt suffixes which derive toponyms (§3.3) with particular stress patterns implies that two zero affixes that also derive toponyms can be postulated in Turkish. In particular, while one zero affix derives toponyms with a particular stress pattern, the other derives toponyms that receive regular Turkish word stress. 


\subsection{Stress in Turkish}

Every word in Turkish has exactly one stress. ${ }^{13}$ The default position of stress in words is final (Lees 1961; Lewis 1967; Sezer 1981; Halle \& Vergnaud 1987; Inkelas 1999; Inkelas \& Orgun 2003, among others). This is true for both inflectional (9a-b) and derivational (9c) domains:
a. şarkí
şarki-lár
şarki-lar-imíz
şarkí-lar-imi̇z-dán
song-PL
Song-PL-POSS.1PL
song-PL-POSS.1PL-ABL
'song'
'songs'
'our songs'
'from our songs'
b. yiká-Ø
$y i k a-d \dot{t}-k$
$y \dot{t} k a-d \dot{t}-n \dot{t} z$
wash-IMP.2SG wash-PST-1PL wash-PST-2PL
'wash!'14 'we washed' 'you washed'
c. göz
göz-lük
göz-lük-çǘ
göz-lük-çü-lǘk
eye-DER 1
eYe-DER1-DER2
eye-DER1-DER2-DER3
'eye'
'eyeglasses' 'optician’
'opticianry'

Final stress is overridden under certain circumstances, for example, in words which contain exceptionally stressed suffixes (suffixes which are always stressed such as the compound verbal affix $\{-\underline{\text { Iver }}\}$ denoting rapid or sudden action (10a)), or pre-stressing suffixes, such as the verbal negation $\{-\overleftarrow{m A}\}$ (10b) (for more environments, see Inkelas \& Orgun 1998; 2003; Inkelas 1999). ${ }^{15}$
a. bak-íver-di-k
cf.
bak-tí-k
look-SUDDEN-PST-1PL
look-PST-1PL
'we rapidly looked (at it)'
'we looked (at it)'
b. $\quad b a ́ k-\overleftarrow{m a}-d \dot{i}-k$
cf.
bak-tí-k
look-NEG-PST-1PL
look-PST-1PL
'we did not look (at it)'
'we looked (at it)' 
More directly relevant to the current discussion is a group of stems that also disrupt the final stress pattern. Sezer (1981) observes that almost all Turkish toponyms (of native or foreign origin) disrupt the final stress pattern. This is called Sezer stress (see also Inkelas 1999) and formulated by Sezer as follows:

In Sezer stems, the stress falls on the antipenultimate syllable if it is heavy (H) [that is, if it is closed or contains long vowel] and the penultimate is light (L); otherwise the stress is on the penultimate.

The Sezer stress pattern is illustrated with monomorphemic toponyms in (11) (from Inkelas 1999: 139, example (10)):

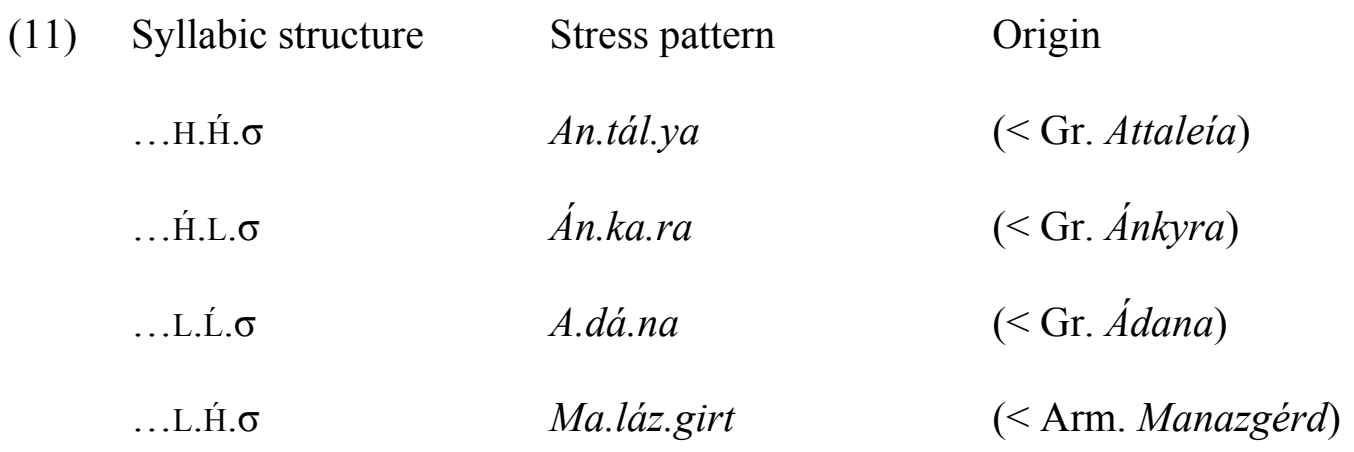

In such cases, Sezer stress overrides final stress, just as exceptionally stressed suffixes or pre-stressing suffixes override final stress:

(12) Antálya
a. Antálya-miz
(cf. *Antalya-míz)
Antalya-POSs.1PL
'our Antalya'
b. Antálya-miz-dan (cf. *Antalya-miz-dán)
Antalya-POSS.1PL-ABL
'from our Antalya' 
It has further been argued that Sezer stress is assigned not only to toponyms but also to certain person names of foreign origin (Sezer 1981), as illustrated in (13). The stress patterns of these names in the source language and in Turkish often do not coincide.

$\begin{array}{ll}\text { (13) Source word } & \text { Turkish } \\ \text { Kénnedy } & \text { Ke.né.di } \\ \text { Papadópulos } & \text { Pa.pa.do.pú.los } \\ \text { Méndelssohn } & \text { Men.dél.son } \\ \text { (Sezer 1981: 64, example (13a)) }\end{array}$

It must be noted that not every name of foreign origin follows this stress pattern. In order to assess the reality of Sezer stress in person names, an experimental study is needed so that a proper correlation between person names and toponyms in terms of stress assignment can be confirmed or refuted, as Inkelas \& Orgun (2003: 143) argue. Due to the lack of sound results in this domain, I leave the issue of person names of foreign origin outside the scope of the paper.

Barker (1989: 7) asserts that Sezer stress is assigned to nouns recently borrowed from other languages as well (14a). In these cases, too, Sezer stress overrides the final stress $(14 b)$ :

$\begin{array}{ll}\text { a. lo.kán.ta } & (<\text { It. locanda }) \\ \text { 'diner' } & \\ \text { a.na.kón.da } & (<\text { Eng. anaconda }) \\ \text { 'anaconda' } & \\ \text { a.çél.ya } & \\ \text { 'azalea' } & (<\text { It. azalea }) \\ \text { a.kás.ya } & \\ \text { 'acacia' acacia })\end{array}$




\section{b. lokánta-miz-dan}

[diner-POSS.1PL-ABL]

'from our diner'

Admittedly, certain loanwords do exhibit Sezer stress (similar to various person names of foreign origin), but this stress pattern is by no means systematic. Thus, along with certain examples that exhibit Sezer stress, such as those in (14) above, there are also numerous (recent) loanwords that conform to the final stress pattern of Turkish (15):

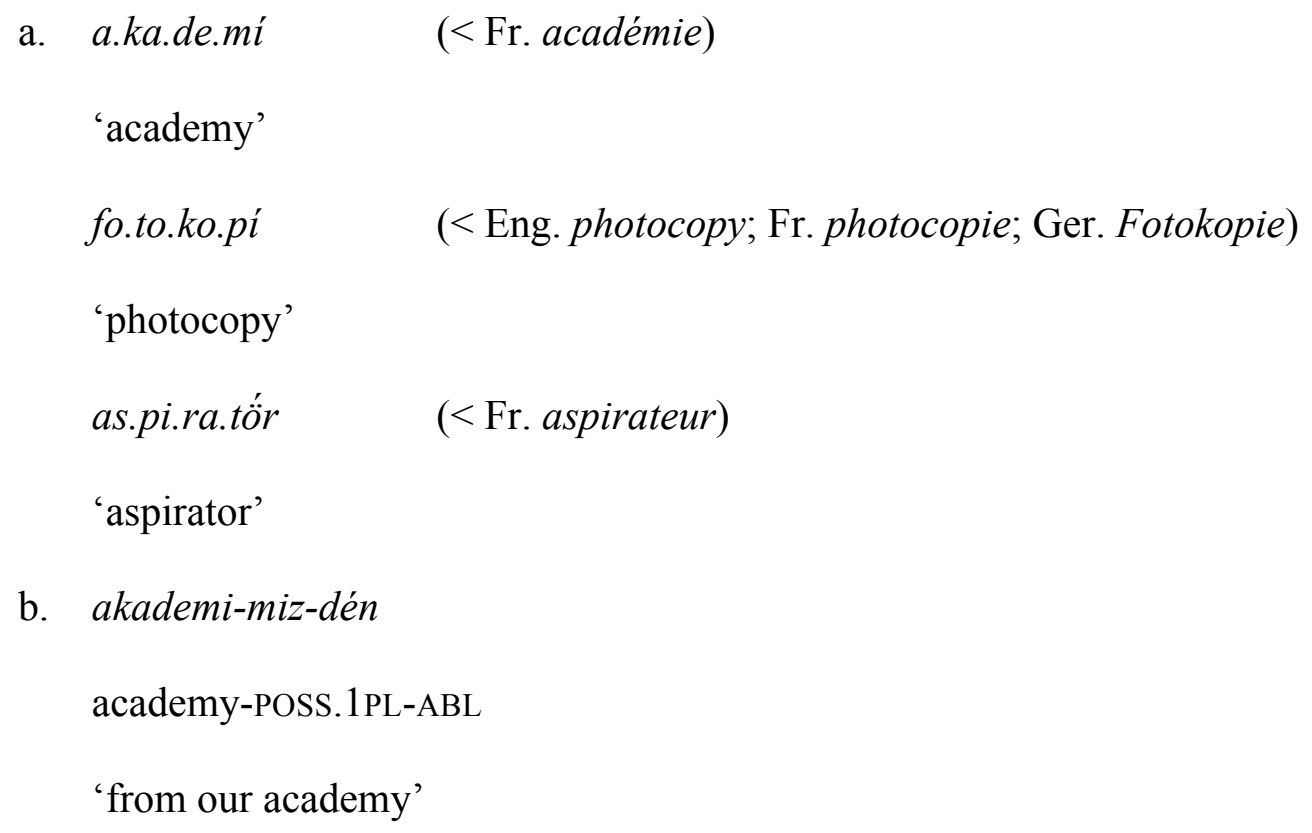

Therefore, the stress pattern in borrowed common words seems to be rather unpredictable, and it does not always reflect the stress pattern of the source language either (Demircan 1975; Sezer 1981). In sum, in line with Inkelas \& Orgun $(1998 ; 2003)$ and Kabak \& Vogel (2001), I assume that stress in such stems is pre-specified as a lexical diacritic feature. I will not pursue the issue of Sezer stress assignment to common nouns any further in this paper, and will proceed to present a case of conversion discussed extensively in Inkelas \& Orgun (2003), that is, conversion of words to toponyms to which Sezer stress is systematically assigned.

\subsection{Conversion to toponyms}


It is not exclusively original toponyms that bear Sezer stress in Turkish. ${ }^{16}$ Virtually any noun or adjective can be converted to a toponym (Sezer 1981: 67; Inkelas \& Orgun 1998: 379; Inkelas \& Orgun 2003: 143). These converted toponyms are also assigned Sezer stress. Monomorphemic examples are provided in (16):

Base

Toponym

a. be.bék

$\rightarrow \quad$ Bé.bek

'baby'

$y \dot{t} l . d t^{\prime} z$

$\rightarrow \quad$ Yúl.dìz

'star'

gü.zél

$\rightarrow \quad$ Gǘ.zel

'beautiful'

b. ki.re.mit

$\rightarrow \quad$ Ki.ré.mit

'roof tile'

yìl.di.rím

$\rightarrow \quad$ Yt́l.dit.rim

'lightning'

Note that in the converted toponyms in both (16a) and (16b), Sezer stress overrides the final stress. Since the words in (16a) are disyllabic, by default the stress is assigned to the penultimate syllable once the words are converted to toponyms. In (16b), in which two monomorphemic polysyllabic examples are given, final stress is once again overridden by Sezer stress when these words are converted to toponyms.

Not only monomorphemic words but also polymorphemic ones can be converted to a toponym. In this case as well, the converted words are assigned Sezer stress (but see also $§ 3.3$ and 3.4 for certain refinements). Some examples are provided in (17):

Base Toponym
a. soğan-lí
$\rightarrow$
So. ̌án.lt́ 
onion-REL

'with onion(s)'

deve-lí $\quad \rightarrow \quad$ De.vé.li

camel-REL

'with camel(s)'

b. kaygí-síz $\quad \rightarrow \quad$ Káy.gí.sizz ${ }^{17}$

worry-PRV

'carefree'

$\begin{array}{lll}\text { su-súz } & \rightarrow & \text { Sú.suz }\end{array}$

water-PRV

'waterless'

c. öde-mişs $\quad \rightarrow \quad$ Ö.dé.miş

pay-EVID

's/he had paid'

üşü-múş̧ $\quad \rightarrow \quad$ U.şü.müş

get cold-EVID

's/he had got cold'

d. bak-acák $\rightarrow \quad$ Ba.ká.cak

look-FUT

's/he will look'

gör-ecék $\rightarrow \quad$ Gö.ré.cek

see-FUT

's/he will see (it)'

e. beğen-dí-k $\rightarrow \quad$ Be.ğén.dik

like-PST-1PL 


'we liked (it)'
sevin-di-k $\quad \rightarrow \quad$ Se.vín.dik
rejoice-PST-1PL
'we rejoiced'

Sezer stress in these converted toponyms also overrides the final stress that would be expected with further affixation. This is exemplified in (18), where it is shown that the Sezer stress of the converted toponym disallows stress shift to the final syllable:
a. Soğánlit-li
(cf. *Sŏganli-lí)
Soğanli-REL
'someone from Soğanli’
b. Soğánlì-lit-lar (cf. *Soğanlì-lì-lár)
Soğanli-REL-PL
'those from Soğanli’

It should also be noted that not every suffix attaching to the base allows for Sezer stress assignment in cases of conversion to toponyms. Words that bear pre-stressing suffixes, such as $\{-\overleftarrow{C A}\}$, keep their stress when they are converted to toponyms (Inkelas 1999: 157). This is illustrated in (19) below.

Base

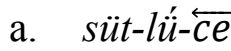

milk-REL-MIT

'kind of milky'

b. $\quad k u m-l u ́-\overleftarrow{c a}$

sand-REL-MIT

'kind of sandy'
Toponym

Süt.lü.ce

*Sǘt.lü.ce

Kum.lú.ca

*Kúm.lu.ca 
The picture emerging so far from the interaction between pre-stressing suffixes, Sezer stress and final stress in the conversion of words to toponyms is captured by Inkelas (1999) by means of the Input Wins generalization. According to this generalization, any stress present in the input to the application of a morphological process that comes along with Sezer stress (conversion) or word stress (suffixation) always prevails according to the hierarchy 'affixation with pre-stressing suffixes' $>$ 'conversion to toponyms' > 'word-formation, that is, affixation (elsewhere)'. For further phonological details, see especially Inkelas (1999).

The question that is directly relevant to the current paper is whether the conversion pattern of both monomorphemic or polymorphemic (16-17) words to toponyms, which involves Sezer stress, should be considered a morphological process, that is, zero-derivation (Marchand 1967; 1969; Kastovsky 1968; 2005). ${ }^{18}$ I will argue in $\S 3.4$ that it is indeed a morphological process of zero affixation.

Zero-derivation involves zero morphemes. It has often been argued in the literature that a prerequisite for the postulation of a zero morpheme in morphology in a given language is the occurrence of overt forms that bear exactly the same function (Sanders 1988: 160-161; Plag 2003: 140-145), a principle often called the Overt Analogue Criterion (Sanders 1988: 140). According to Sanders, a zero morpheme is justified in the conversion pair answer ${ }^{\mathrm{V}} \rightarrow$ answer $^{\mathrm{V}}-\varnothing^{\mathrm{N}}$ because there is a correlated overt suffix with the same meaning or function as the zero-morpheme, as in announce $\mathrm{V}$ $\rightarrow$ announce $^{\mathrm{V}}-$ ment $^{\mathrm{N}}$. The obvious question that emerges now is whether conversion to toponyms in Turkish also involves zero-morphemes that can be justified by virtue of the Overt Analogue Criterion. I will address this issue in the next section.

\subsection{Toponyms derived via overt suffixation}


Not every toponym in Turkish comes into being via conversion. As a consequence, not every toponym is assigned Sezer stress. In this section, reproducing the argument by Inkelas \& Orgun (2003), I present three cases of derivation of toponyms with overt suffixes that are in complementary distribution. This presentation will eventually justify the proposal of a zero affix in the derivation of toponyms as described in $\S 3.2$, which is itself in complementary distribution with the overt suffixes. It will turn out that only the process of derivation of toponyms with the zero affix involves Sezer stress.

The first suffix that derives toponyms is the pre-stressing suffix $\{-\overleftarrow{l y e}\}(<\mathrm{Ar}$. iyya). This suffix attaches to proper names of Arabic or Persian origin (20a) or to executive titles (20b): ${ }^{19,20}$

$$
\text { Toponym Base }
$$

a. Reşá:d-

\begin{tabular}{|c|c|c|}
\hline 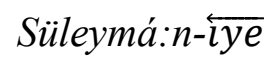 & $\leftarrow$ & Süleyman \\
\hline 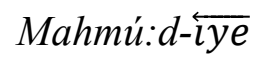 & $\leftarrow$ & Mahmut \\
\hline 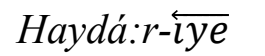 & $\leftarrow$ & Haydar \\
\hline
\end{tabular}

b. Sultá:n-官e $\quad \leftarrow \quad$ sultan

'sultan'

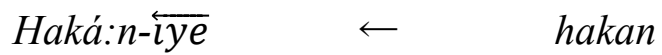

'khan'

Similar to other pre-stressing suffixes, $\{-\overleftarrow{\imath y e}\}$ also disrupts the default final stress (as a consequence of the Input Wins generalization). This is exemplified in (21) below. The primary stress of toponyms derived via $\{-\overleftarrow{l y e}\}$-suffixation does not shift to final position when inflectional suffixes are added:

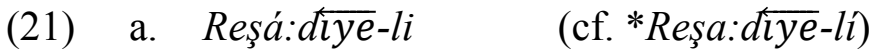

Reşadiye-REL 
'who is from Reşadiye'

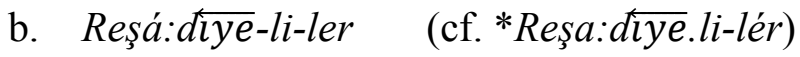

Reşadiye-REL-PL

'those from Reşadiye'

The second suffix that forms toponyms is $\{-i s t a n\}(<$ Far. - stan), which attaches to ethnonyms (22). ${ }^{21}$ This is a stress-neutral suffix; therefore, toponyms derived via this suffix conform to the final stress pattern of Turkish (23).

(22)

$\begin{array}{lll}\text { Hind(i)-istán } & \leftarrow & \text { Hindi } \\ \text { 'India' } & \leftarrow & \text { 'Indian' } \\ \text { Moğol-istánol } \\ \text { 'Mongolia' } & & \text { 'Mongol' } \\ \text { Yunan-istán } & \leftarrow & \text { Yunan } \\ \text { 'Greece' } & & \text { 'Greek' }\end{array}$

(23) a. Hindistan-lt́

India-REL

'who is from India'

b. Hindistan-lì-lár

India-REL-PL

'those from India'

Finally, the suffix $\{-h a: n e\}$ ( $<$ Far. xāna 'house') attaches to non-derived common nouns to derive toponyms (24). Similar to the suffix $\{-(i) \operatorname{stan}\},\{-h a: n e\}$ is also a stressneutral suffix (25):

(24) Kă̈̀tt-ha:né

$\leftarrow \quad k a \breve{g} \dot{t} t$

'paper'

Top-ha:né

$\leftarrow \quad t o p$ 
Gümüş-ha:né $\quad \leftarrow \quad$ gümüşs

'silver'

(25) a. Kă̈tha:ne-lí

Kağithane-REL

'who is from Kağithane'

b. Kağitha:ne-li-lér

Kağithane-REL-PL

'those from Kağithane'

The properties of the three overt suffixes presented so far are summarized in Table 1.

Table 1: Overt suffixes forming toponyms in Turkish

\begin{tabular}{lllr}
\hline Suffix & Stress & Base & Example \\
\hline -iye & pre-stressing & proper names/executive titles & $(20)$ \\
-istan & stress-neutral & ethnonyms & $(22)$ \\
-ha:ne & stress-neutral & non-derived common nouns & (24) \\
\hline
\end{tabular}

These three suffixes are in complementary distribution with one another (Inkelas \& Orgun 2003: 150). The bases that accept one of the toponymic suffixes resist the others. For example, no toponym derived via $\{$-istan $\}$ suffixation to a proper name exists (*Ahmed-istan vs. Ahmé:d-iye), nor does any toponym derived via the attachment of \{-

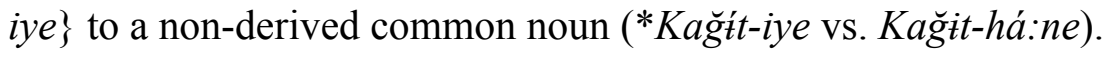

\subsection{Zero affixes in derived toponyms}

The existence of such overt suffixes forming toponyms (\$3.3) satisfies the Overt Analogue Criterion and justifies the postulation of a zero affix that operates as the elsewhere suffix to derive toponyms from both derived and non-derived words. The 
three overt suffixes are rather specific in terms of the features/category of the bases they attach to: $\{-i y e\}$ attaches only to proper names of Arabic or Persian origin, and to executive titles, $\{-i s t a n\}$ attaches only to ethnonyms, and $\{-h a: n e\}$ attaches to nonderived common nouns. As we saw in $\S 3.2$, however, these three affixal derivations are not the only morphological processes used for forming toponyms: both monomorphemic and polymorphemic words can also be readily converted to toponyms without an overt suffix. Taking the Overt Analogue Criterion seriously and in line with Inkelas \& Orgun (2003), it is then safe to assume that conversion of such derived or non-derived words to toponyms is also an affixal derivational process, involving a zero affix. $^{22}$

The assignment of Sezer stress to these words (as long as the Input Wins generalization is observed), then, can be neatly captured within Co-phonology Theory (Orgun 1996; 1998; Inkelas et al. 1997; Inkelas 1998; Anttila 2002, among others). According to this theory, each specific morphological process (that is, construction) is associated with a different sub-grammar, its co-phonology, which is the phonological function of the process along with its semantic and syntactic functions. In Turkishone stress-pattern(word-level stress) is assigned by the word-level co-phonology, which is the phonological function of the word construction; another stress pattern (Sezer stress) is assigned by the co-phonology of toponym formation. These are schematized in Figure 1 and Figure 2 respectively.

\section{Figure 1: Properties of word construction}

$$
\text { Word construction: }\left[\begin{array}{ll}
\text { Syntax: } & \text { Word } \\
\text { Co-phonology: } & \text { Final stress }
\end{array}\right]
$$




\section{Figure 2: Properties of toponym construction}

$$
\text { Toponym construction: }\left[\begin{array}{ll}
\text { Syntax: } & \text { Toponym } \\
\text { Co-phonology: } & \text { Sezer stress }
\end{array}\right]
$$

In effect then, while the zero affix is responsible for the derivation of toponyms from monomorphemic/polymorphemic bases, Sezer stress is assigned by the sub-grammar of the toponym-forming pattern via zero affixation. The Sezer stress can then be considered to mark membership in the class of toponyms. ${ }^{23}$

The zero affix, whose co-phonology also assigns Sezer stress, contrasts not only with the overt suffixes discussed in $\S 3.3$, but also with another zero affix that forms toponyms but differs from the previous one in that, in this construction, Sezer stress is not assigned and the derivative conforms to default word final stress. I will henceforth gloss the zero affix that assigns Sezer stress as $\left\{-\varnothing_{1}\right\}$ and the the zero affix that does not assign Sezer stress as $\left\{-\varnothing_{2}\right\}$. In principle, $\left\{-\varnothing_{2}\right\}$ attaches either to words that carry the plural marking -lAr (26a) or to bases that carry the third person negative aorist marker $\{-m A z\}$ (26b) (Orgun 1996; Inkelas \& Orgun 2003). These derived toponyms are not assigned Sezer stress, and stress shifts to the final syllable when further inflectional suffixes follow (27).
a. Kaya-lár

rock-PL

Hoca-lár

hodja-PL

Hasan-lár 
Hasan-PL

b. Söyle-méz

Say-NEG.AOR

Terle-méz

sweat-NEG.AOR

(27) a. Kayalar-lí

Kayalar-REL

'who is from Kayalar'

Kayalar-lì-lár

Kayalar-REL-PL

'those from Kayalar'

b. Söylemez-li

Söylemez-REL

'who is from Söylemez'

Söylemez-li-lér

Söylemez-REL-PL

'those from Söylemez'

The $\left\{-\varnothing_{2}\right\}$ suffix is productive, is in complementary distribution with the other toponym-forming zero-suffix $\left\{-\varnothing_{1}\right\}$, and subcategorizes for words that are affixed by $\{-$ $l A r\}$ or $\{-m A z\}$. In that sense, similar to toponym-forming patterns with overt suffixes (cf. §3.3), the toponym-forming pattern with $\left\{-\varnothing_{2}\right\}$-affixation constitutes a more specific pattern than the toponym-forming pattern with $\left\{-\varnothing_{1}\right\}$-affixation, which is the elsewhere case. Since $\left\{-\varnothing_{2}\right\}$-affixation is not associated with a co-phonology that assigns Sezer stress, the outputs of this construction are sent to word construction, which is associated with default final stress. The properties of all affixes that form 
toponyms in Turkish are summarized in Table 2 (updated from Table 1; see also Inkelas \& Orgun 2003: 150).

Table 2: Toponym-forming suffixes in Turkish

\begin{tabular}{lllr}
\hline Suffix & Stress pattern & Base & Example \\
\hline -iye & pre-stressing & proper names/executive titles & $(20)$ \\
-istan & stress-neutral & ethnonyms & $(22)$ \\
- ha:ne & stress-neutral & non-derived common nouns \\
$-\emptyset_{1}$ & Sezer stress & elsewhere \\
$-\emptyset_{2}$ & stress-neutral & bases ending in $\{-l A r\}$ and $\{-m A z\}$ & $(24)$ \\
& & &
\end{tabular}

Admitting zero affixes in the process of conversion of monomorphemic or polymorphemic words to toponyms also implies that the converted toponyms (both via $\left\{-\varnothing_{1}\right\}$ - and $\left\{-\varnothing_{2}\right\}$-affixation) are outputs of morphological and, more specifically, derivational processes, just like their analogues that derive via overt suffixation. In this sense, conversion (which is identical to zero-derivation in this study) only constitutes a subset of the general set of toponym-forming processes in Turkish, along with others that employ overt suffixes. Each process is associated with its own formative (overt or zero affixes) and its own co-phonology, which is responsible for the assignment of a particular type of stress.

Once we recognize derivation of toponyms by zero affixation as a conversion process, an interesting issue arises. Conversion has generally been taken as a process that links formally identical lexemes that nevertheless belong to different word classes, which reflect the findings of traditional scholarship (nouns, adjectives, verbs and/or adverbs; cf. among others van Marle 1985: 144-5; Olsen 1990: 188; Plag 1999: 219_ 220, Anward 2001: 726-727; Farrell 2001; Bauer \& Valera 2005: 8; Valera 2015: 163; 
see also the definition given in $§ 1)$. Bauer \& Valera (2005: 10-11) pose two questions related to word classes that should be considered. The first concerns the multiple class membership of certain lexemes (see $\$ 2.1$ for cases in Turkish and the discussion on this question). The second, which is more directly related to the current discussion, is how narrowly word classes should be defined. For example, nouns, as Bauer \& Valera (2005) state, can be divided into common and proper nouns, animate and inanimate nouns, concrete and abstract nouns and so on, as long as there is a principled reason for such partitioning, and as long as conversion between subclasses of word categories (also known as secondary word-class conversion) is justified.

The conversion of monomorphemic and polymorphemic words to toponyms by zero affixes in Turkish can be taken as such cases of secondary word-class conversion. This process implies the existence of a subclass of toponyms in the realm of nouns in Turkish. In a similar vein, Anderson $(2004 ; 2007)$ independently argues that (proper) names have a distinctive morphosyntax from other syntactic categories (see also the papers in Schlücker \& Ackermann 2017). According to Anderson, at the core of this class lie person names, which lack a persistent referent, and hence would be farthest from common nouns on a continuum. Only when persistent reference is established, that is, when the person name is institutionalized, can it become a base for further morphological derivation, as in Marx-ist, Chomsky-an. ${ }^{24}$ Otherwise, name morphology cannot be identified with noun morphology (an idea also put forward by Kuryłowicz 1966). More directly related to the current paper is Anderson's argument that toponyms are morphosyntactically different from person names. Toponyms have a relatively persistent referent. The differences between toponyms and person names surface in various places cross-linguistically. For example, unlike person names, toponyms usually need a classifying noun such as lake, city or mountain. Moreover, in various languages, 
toponyms can be inflected similarly to common nouns but unlike person names (for example, Basque locatives; see Anderson 2003: 355; example (15)). Hence, Anderson argues that toponyms are non-core (proper) names. This makes them more akin to common nouns and more prone to derivation, as in Istanbul-ite, London-er, Paris-ian.

Conversion from monomorphemic and polymorphemic words to toponyms in Turkish also indirectly reveals that toponyms form a special sub-class among the class of nominals, not only semantically but also formally differentiated from the rest. The members of this category can be non-derived or derived by a number of affixes, among which are also two zero affixes. These zero affixation processes are instances of secondary class conversion.

\section{Conclusions}

This paper has provided an overview of possible cases of conversion in Turkish. It first argued that there is no morphological conversion between nouns and adjectives in Turkish. It was argued that apparent cases of conversion are better handled as reversible syntactic transposition. The paper then investigated apparent cases of conversion between nouns/adjectives and verbs. Close diachronic inspection revealed that what appear to be pairs of lexemes related to each other by (syntactic transposition or) conversion in reality are homonyms, homonymy being the accidental result of certain phonological changes in the history of the language. These two cases have yielded the generalization that conversion between primary word classes is not available as a morphological process in Turkish (yet this generalization does not take into consideration other possible primary word classes, for example, adverbs). This, however, does not mean that Turkish does not have morphological conversion. Based on the analysis developed in Inkelas \& Orgun (2003), I showed that there are two clear cases of morphological conversion that form toponyms from monomorphemic or 
polymorphemic words. That means that conversion, although not available in Turkish between primary word classes, can nevertheless be said to exist as a process that creates members of a secondary word class.

\section{Acknowledgements}

I would like to thank Marios Andreou, Salvador Valera and two anonymous reviewers for their most constructive remarks and suggestions, and the guest editors for their help with the editing. Needless to say, all errors are mine. I gratefully acknowledge the Research Foundation Flanders (FWO) for their financial support (Grant no: FWO13/ASP/010).

\section{Abbreviations}

Abbreviations follow the Leipzig Glossing Rules. Other abbreviations used for this paper are:

$\begin{array}{llll}\text { Ar. } & \text { Arabic } & \text { It. } & \text { Italian } \\ \text { Arm. } & \text { Armenian } & \text { MIT } & \text { mitigative } \\ \text { DER } & \text { derivational suffix } & \text { NEG.AOR } & \text { negative aorist } \\ \text { Eng. } & \text { English } & \text { OT } & \text { Old Turkic } \\ \text { EVID } & \text { evidential } & \text { PRV } & \text { privative } \\ \text { Far. } & \text { Persian } & \text { RED } & \text { reduplicative } \\ \text { Fr. } & \text { French } & \text { REL } & \text { relational } \\ \text { Ger. } & \text { German } & \text { SUDDEN } & \text { sudden action } \\ \text { Gr. } & \text { Greek } & \text { tr } & \text { transitive } \\ \text { intr. } & \text { intransitive } & & \end{array}$

\section{References}

Anderson, John. 2004. On the grammatical status of names. Language 80. 435-474.

Anderson, John. 2007. The grammar of names. Oxford: Oxford University Press. 
Anttila, Arto. 2002. Morphologically conditioned phonological alternations. Natural Language \& Linguistic Theory 20. 1-42.

Anward, Jan. 2001. Parts of speech. In Haspelmath, Martin, König, Ekkehard, Oesterreicher, Wulf \& Raible, Wolfgang (eds.), Language typology and language universals, vol. 1, 726-735, Berlin: de Gruyter.

Atabay, Neşe, Kutluk, İbrahim \& Özel, Sevgi. 1983. Sözcük türleri [Word types]. Ankara: Türk Dil Kurumu.

Bağrıçık, Metin \& Ralli, Angela. 2013. Bare N(ominal) N(ominal) concatenations in Turkish: Compounds or syntactic fallacies? In Hathout, Nabil, Montermini, Fabio \& Tseng, Jesse (eds.), Morphology in Toulouse. Selected proceedings of Décembrettes 7, Toulouse, 2-3 December 2010, 35-56. Munich: Lincom.

Baker, Mark. 2004. Lexical categories: Verbs, nouns and adjectives. Cambridge: Cambridge University Press.

Banguoğlu, Hasan. 1990. Türkçe’nin grameri [The grammar of Turkish]. Ankara: Türk Dil Kurumu.

Barker, Christopher. 1989. Extrametricality, the cycle, and Turkish word stress. In Itô, Junko \& Runner, Jeff (eds.), Phonology at Santa Cruz 1, 1-33. Santa Cruz, CA: Linguistics Research Center.

Baskakov, Nikolaj. 1958. Altajskij jazyk: Vvedenie v izučenie altajskogo jazyka i ego dialektov [Altaic language: Introduction to the study of the Altaic language and its dialects]. Moscow: Izdatel'stvo Akademii Nauk SSSR.

Bauer, Laurie \& Valera, Salvador. 2005. Conversion or zero-derivation: An introduction. In Bauer, Laurie \& Valera, Salvador (eds.), Approaches to conversion/zero-derivation, 7-17. Münster: Waxmann. 
Bermúdez-Otero, Ricardo. 2012 The architecture of grammar and the division of labor in exponence. In Trommer, Jochen (ed.), The morphology and phonology of exponence, 883. Oxford: Oxford University Press.

Bhat, Darbhe. 1994. The adjectival category: Criteria for differentiation and identification. Amsterdam: John Benjamins.

Bloomfield, Leonard. 1933. Language. New York, NY: Holt, Rinehart and Winston.

Braun, Friederike \& Haig, Geoffrey. 2000. The noun/adjective distinction in Turkish: An empirical approach. In Göksel, Aslı \& Kerslake, Celia (eds.), Studies on Turkish and Turkic languages: Proceedings of the ninth international conference on Turkish linguistics, 85-92. Wiesbaden: Harrassowitz.

Chomsky, Noam. 1970. Remarks on nominalization. In Jacobs, Roderick A. \& Rosenbaum, Peter S. (eds.), Readings in English Transformational Grammar, 184-221. Boston, MA: Ginn.

Clauson, Gerard. 1972. An etymological dictionary of pre-thirteenth-century Turkish. Oxford: Clarendon Press.

Demircan, Ömer. 1975. Türk dilinde vurgu. Sözcük vurgusu [Stress in Turkish. Word stress]. Türk Dili 284. 333-339.

Dokulil, Miloš. 1968a. Zur Frage der Konversion und verwandter Wortbildungsvorgänge und beziehungen. Travaux linguistiques de Prague 3. 215-239.

Dokulil, Miloš. 1968b. Zur Frage der sog. Nullableitung. In Brekle, Herbert E. \& Lipka, Leonhard (eds.), Wortbildung, Syntax und Morphologie, 55-64. The Hague: Mouton.

Don, Jan. 1993. Morphological conversion. Utrecht: Utrecht University. (Doctoral dissertation.)

Don, Jan. 2005. On conversion, relisting and zero-derivation. SKASE Journal of Theoretical Linguistics 2. 2-16.

Ediskun, Haydar. 1992. Türk dilbilgisi [Turkish grammar]. İstanbul: Remzi Kitabevi.

Eker, Süer. 2003. Çăgdaş Türk dili [Modern Turkish]. Ankara: Grafiker Yayınları. 
Erdal, Marcel. 1991. Old Turkic word formation. A functional approach to the lexicon, vols. 1 \& 2. Wiesbaden: Harrassowitz.

Erdal, Marcel. 2004. A grammar of Old Turkic. Leiden: Brill.

Farrell, Patrick. 2001. Functional shift as category underspecification. English Language and Linguistics 5. 109-130.

Gencan, Tahir. 2001. Dilbilgisi [Grammar]. Ankara: Ayraç Yayınları.

Godel, Robert. 1945. Grammaire turque. Geneva: University of Geneva.

Gökdayı, Hürriyet. 2007. Takısız ad tamlamaları [Bare noun compounds]. In Károly, László (ed.), Turcology in Turkey: Selected papers, 243-252. Szeged: SzTE BTK Altjisztikai Tanszék.

Göksel, Aslı \& Kerslake, Celia 2005. Turkish. A comprehensive grammar. London: Routledge. Grønbech, Kaare. 1936. Der türkische Sprachbau, 1. Copenhagen: Levin \& Munksgaard.

Halle, Morris \& Vergnaud, Jean-Roger. 1987. An essay on stress. Cambridge, MA: MIT Press.

Haltod, Mattai, Hangin, John G., Kassatkin, Serge \& Lessing, Ferdinand D. 1960. MongolianEnglish dictionary. Berkeley, CA: University of California.

Harris, Alice. 2006. Revisiting anaphoric islands. Language 82. 114-130.

Hatipoğlu, Vecihe. 1972. Türkçe'nin sözdizimi [The syntax of Turkish]. Ankara: Türk Dil Kurumu.

Inkelas, Sharon. 1998. The theoretical status of morphologically conditioned phonology: A case study of dominance effects. Yearbook of Morphology 1997. 121-155. Dordrecht: Kluwer.

Inkelas, Sharon. 1999. Exceptional stress-attracting suffixes in Turkish: Representations vs. the grammar. In Kager, René, van der Hulst, Harry \& Zonneveld, Wim (eds.), The prosodymorphology interface, 134-187. Cambridge: Cambridge University Press.

Inkelas, Sharon \& Orgun, Cemil Orhan. 1998. Level (non)ordering in recursive morphology: Evidence from Turkish. In Lapointe, Steven, Brentari, Diane \& Farrell, Patrick (eds.), 
Morphology and its relation to phonology and syntax, 360-392. Stanford, CA: CSLI Publications.

Inkelas, Sharon \& Orgun, Cemil Orhan. 2003. Turkish stress: A review. Phonology 20. 139-161. Inkelas, Sharon, Orgun, Cemil Orhan \& Zoll, Cheryl. 1997. The implications of lexical exceptions for the nature of grammar. In Roca, Iggy (ed.), Derivations and constraints in phonology, 393-418. Oxford: Clarendon Press.

Jackendoff, Ray. 1997. The architecture of the language faculty. Cambridge, MA: MIT Press.

Johanson, Lars. 1990. Studien zur türkeitürkischen Grammatik. In Hazai, György (ed.), Handbuch der türkischen Sprachwissenschaft, vol. 1, 146-278. Budapest: Akadémiai Kiadó.

Kabak, Barış \& Vogel, Irene. 2001. The phonological word and stress assignment in Turkish. Phonology 18. 315-360.

Kastovsky, Dieter. 1968. Old English deverbal substantives derived by means of a zero morpheme. Esslingen/N.: B. Langer.

Kastovsky, Dieter. 2005. Conversion and/or zero: Word-formation theory, historical linguistics, and typology. In Bauer, Laurie \& Valera, Salvador (eds.), Approaches to conversion/zeroderivation, 31-49. Münster: Waxmann.

Kayne, Richard. 2005. Movement and silence. Oxford: Oxford University Press.

Kayne, Richard. 2015. The silence of heads. Studies in Chinese Linguistics 37. 1-37.

Kiefer, Ferenc. 2005. Types of conversion in Hungarian. In Bauer, Laurie \& Valera, Salvador (eds.), Approaches to conversion/zero-derivation, 51-65. Münster: Waxmann.

Kim, Ga Hyun. 2010. Synchrony and diachrony of conversion in English. Edinburgh: University of Edinburgh. (MA thesis.) 
Kiparsky, Paul. 1982. Lexical phonology and morphology. In Yang, In-Seok (ed. on behalf of the Linguistic Society of Korea), Linguistics in the morning calm: Selected papers from SICOL 1981, vol. 1, 3-91. Seoul: Hanshin.

Koç, Nuretin. 1995. Yeni dilbilgisi [New grammar]. İstanbul: İnkılap Kitabevi.

Korkmaz, Zeynep. 2003. Türkiye Türkçesi grameri (şekil bilgisi) [The grammar of Turkish: (morphology)]. Ankara: Türk Dil Kurumu.

Kornfilt, Jaklin. 1997. Turkish. London: Routledge.

Kuryłowicz, Jerzy. 1966. La position linguistique du nom proper. In Hamp, Eric, Joos, Martin, Householder, Fred \& Austerlitz, Robert (eds.), Readings in linguistics II, 362-70. Chicago, IL: University of Chicago Press.

Lees, Robert. 1961. The phonology of modern standard Turkish. Bloomington, IN: Indiana University Publications.

Lewis, Geoffrey. 1967. Turkish grammar. Oxford: Clarendon Press.

Lieber, Rochelle. 1981. Morphological conversion within a restrictive theory of the lexicon. In Moortgat, Michael, van der Hulst, Harry, \& Hoekstra, Teun (eds.), The scope of lexical rules, 161-200. Dordrecht: Foris.

Lieber, Rochelle. 2004. Morphology and Lexical Semantics. Cambridge: Cambridge University Press.

Lieber, Rochelle. 2005. English word-formation processes. In Štekauer, Pavol \& Lieber, Rochelle (eds.), Handbook of word-formation, 374-427. Dordrecht: Springer.

Manova, Stela \& Dressler, Wolfgang U. 2005. The morphological technique of conversion in the inflecting-fusional type. In Bauer, Laurie \& Valera, Salvador (eds.), Approaches to conversion/zero-derivation, 67-101. Münster: Waxmann.

Marchand, Hans. 1967. Expansion, transposition and derivation. La Linguistique 3. 13-26. 
Marchand, Hans. 1969. The categories and types of present-day English word-formation. 2nd edn. Munich: Beck.

van Marle, Jaap. 1985. On the paradigmatic dimension of morphological creativity. Dordrecht: Foris.

Nişanyan, Sevan. 2016. Çağdaş Türkçe'nin etimolojisi [The etymology of Modern Turkish]. (http://www.nisanyansozluk.com) (Accessed 2016-07-29.)

Olsen, Susan. 1990. Konversion als kombinatorischer Wortbildungsprozeß. Linguistische Berichte 127. 185-216.

Orgun, Cemil Orhan. 1996. Sign-based morphology and phonology with special attention to Optimality Theory. Berkeley, CA: University of California. (Doctoral dissertation.)

Orgun, Cemil Orhan. 1998. Cyclic and noncyclic phonological effects in a declarative grammar. Yearbook of Morphology 1997. 179-218. Dordrecht: Kluwer.

Plag, Ingo. 1999. Morphological productivity: Structural constraints in English derivation. Berlin: de Gruyter.

Plag, Ingo. 2003. Word-formation in English. Cambridge: Cambridge University Press.

Quirk, Randolph, Greenbaum, Sidney, Leech, Geoffrey \& Svartnik, Jan. 1985. A comprehensive grammar of the English language. London: Longman.

Sanders, Gerald. 1988. Zero derivation and the Overt Analogue Criterion. In Hammond, Michael \& Noonan, Michael (eds.), Theoretical morphology, 155-175. San Diego, CA: Academic Press.

Schlücker, Barbara \& Ackermann, Tanja (eds.). 2017. Special issue: The morphosyntax of proper names. Folia Linguistica 51(2).

Sezer, Engin. 1981. On non-final stress in Turkish. Journal of Turkish Studies 5. 61-69.

Swift, Lloyd. 1963. A reference grammar of modern Turkish. The Hague: Mouton.

Štekauer, Pavol. 1996. A theory of conversion in English. Frankfurt am Main: Peter Lang. 
Štekauer, Pavol. 2005. Onomasiological approach to word formation. In Lieber, Rochelle \& Štekauer, Pavol (eds.), The Oxford handbook of derivational morphology, 206-232. Oxford: Oxford University Press.

TDK. 1972. Türk dil kurumu derleme sözlüğ̈̈ [Dialectal dictionary of the Turkish Language Association], vol. 5, E-F. Ankara: Türk Dil Kurumu.

Tekin, Talât. 1968. A grammar of Orkhon Turkic. Bloomington, IN: Indiana University.

Valera, Salvador. 2015. Conversion. In Lieber, Rochelle \& Štekauer, Pavol (eds.), The Oxford handbook of derivational morphology, 154-168. Oxford: Oxford University Press.

Zülfikar, Hamza. 1995. Takısız ad tamlaması sorunu [The problem of bare noun compounds]. Türk Dili 523. 781-789.

Author's address: $\quad$ (Metin Bağrıaçı)

Department of Linguistics

Ghent University

Blandijnberg 2, 9000

Ghent

Belgium

E-mail: Metin.Bagriacik@UGent.be 


\section{Notes}

${ }^{1}$ Turkish examples throughout the paper are given in the standard Turkish orthography with the following three exceptions: i) $<_{1}>[\mathrm{w}]$ is given as $<\dot{\mathrm{i}}>$; ii) stress, which is not indicated in the standard orthography, is indicated where necessary; and iii) vowel length is indicated by a colon (:) if necessary. Hyphens (-) show morpheme boundaries, and syllable boundaries are indicated by periods (.). The asterisk (*) is employed both for ungrammatical examples and for unattested, constructed examples in Old Turkic. Letters in capitals denote underlying phonemes whose surface value is determined by assimilatory rules.

${ }^{2}$ Erdal (1991: 132, footnote 187) states for Old Turkic that "[ $\left.t\right]$ he question is not whether a given lexeme can be put solely to nominal or solely to adjectival use, but what the addressee or reader takes it to be, where the text gives him no clue for choice".

${ }^{3}$ This process is akin to that of syntactic conversion or re-categorization (cf. Manova \& Dressler 2005).

${ }^{4}$ As an extension of this debate, there is no consensus on whether concatenations such as $\operatorname{tas}$ duvar 'stone wall' (cf. taş ${ }^{\text {Adj/N }}$ 'stone'), are adjective-noun or noun-noun compounds/phrases either. According to Hatipoğlu (1972: 18), Atabay et al. (1983: 56), Koç (1995: 432-436), Gencan (2001: 188-189) and Eker (2003: 366), they are noun-noun compounds. According to Banguoğlu (1990: 345), Ediskun (1992: 122-123), Zülfikar (1995: 789), Korkmaz (2003: 275) and Gökdayı (2007), they are adjective-noun compounds. See also Bağriaçık \& Ralli (2013), who argue that such concatenations form a continuum between pure phrases and compounds.

$5 / \mathrm{d} />/ \mathrm{j} /$ and $/ \mathrm{o} />/ \mathrm{a} /$ changes from Old Turkic to Middle Turkic are frequent phonological changes.

${ }^{6}$ The verbal base is not attested in Old Turkic. See, however, its cognate in written Mongolian nigsi- 'to become spoiled or rancid (of food)' (Haltod et al. 1960: 582). 
${ }^{7}$ The suffix has possibly merged with the already existing but uncommon deverbal nominal suffix $-I$ of Old Turkic.

${ }^{8}$ As a reviewer points out, köč 'migration, load' in Old Turkic is likely to have come from a syncopation of *köč- $\ddot{u} \check{s}$.

${ }^{9}$ In some Anatolian Turkish dialects, the verb form is distinct from the nominal form, that is, eskir- vs. eski (TDK 1972). See also the forms in Tatar, iske 'old' vs. isker- 'to be worn out', in Kazakh, eski 'old' vs. eskir- 'to be worn out'.

${ }^{10}$ As a reviewer correctly points out, qari did however survive into Turkish with the meaning 'wife'.

${ }^{11}$ Nonetheless in various other Turkic languages, both the nominal and the verbal forms are retained, for example, Azeri $a c$ 'hungry' and $a c$ - 'to feel hungry'.

${ }^{12}$ Needless to say, this view overlooks possible conversion between other word classes such as between adjectives and adverbs.

${ }^{13}$ Word is taken to be "[...] a free form which does not consist entirely of (two or more) lesser free forms" (Bloomfield 1933: 178). This may correspond to $\mathrm{X}^{0}$ or XP in Turkish (if pieces of inflection are taken to project their own phrases).

${ }^{14}$ Bare verbal stems correspond to second singular imperative forms. Still, a zero morpheme can be postulated in this case.

${ }^{15}$ Some authors argue that $\{-I v e r\}$ is not a suffix but a compound verb construction, involving the gerundive $\{-(y) I\}$ and the verb stem ver- 'give' (for example, Kornfilt 1997: 361). The semantic opacity of the alleged verb root ver-, however, raises the issue of grammaticalization of the $\{-(y) I\}+v e r$ - concatenation.

${ }^{16}$ Note, however, that even among toponyms of foreign origin, there are some to which Sezer stress is not assigned: 
i) Stress position

Expected Sezer stess

Af.ri.ka

*Áf.ri.ka

'Africa'

In.gil.té.re

*In.gíl.te.re

'England'

Bel.çíka

*Bél.çi.ka

'Belgium'

Av.rú.pa

*Áv.ru.pa

'Europe'

$\ddot{U} s . k u ̈ . d a r$

* Üs.kü.dar

'a municipality in Istanbul'

Kas.tá.mo.nu

*Kas.ta.mó.nu

'a city in Turkey'

Another example, A.na.do.lu' 'Anatolia' has unexpected final stress. According to a database search by Inkelas \& Orgun (2003), 135 out of 143 polysyllabic monomorphemic toponyms (96\%), and all of the 203 disyllabic monomorphemic toponyms (100\%) are consistent with Sezer stress. As we will see in the rest of the paper, the existence of polysyllabic monomorphemic toponyms (4\% in Inkelas \& Orgun 2003) that do not conform to Sezer stress pattern does not bear on the rather systematic assignment of Sezer stress to (a subset of derived) toponyms.

${ }^{17}$ Note that not every native speaker accepts the Sezer stress in this example.

${ }^{18}$ For alternative approaches to conversion, see, among others, Štekauer (1996; 2005: 219-221), Don $(1993 ; 2005)$ or Lieber $(1981 ; 2004: 89-95 ; 2005$ : 418-422). In this paper, I provide a zeroderivation approach to conversion (cf. Marchand 1967; 1969; Kastovsky 1968; 2005). 
${ }^{19}$ The lengthening of the final vowel is quite common, but not unexceptional, for example,

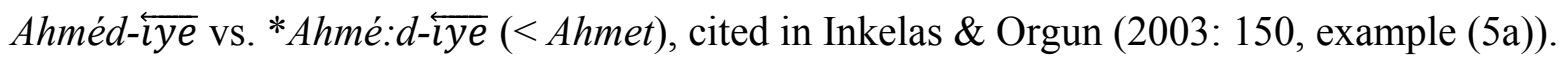

${ }^{20}$ There are also two instances where the suffix apparently attaches to ethnonyms: Türk- $\overleftarrow{l y e}$

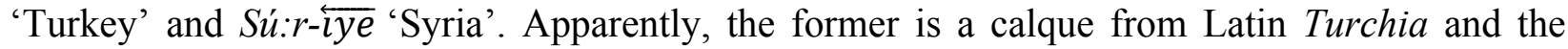
latter is directly borrowed from Arabic.

${ }^{21}$ As a reviewer rightly points out, Elbistan (in southeastern Turkey) is not derived from an ethnonym via the $\{-i s t a n\}$ suffix: it comes from the Arabic word Ablastayn. Pakistan does not seem to be derived from an ethnonym either; cf. Persian/Urdu pāk 'pure' (hence Pakistan 'the land of the pure').

${ }^{22}$ One reviewer argues that the stress change observed in the derivation of toponyms is a suprasegmental change. This means that what is involved in this derivation is not a zero affix but a real, phonetically realized element; therefore, the derivation of toponyms should not be associated with conversion. Similar instances, such as verb-to-noun conversions in English, which involve stress shift (for example, tormént ${ }^{\mathrm{V}}$ vs. tórment $^{\mathrm{N}}$ ), have also been categorized as conversion with formal modifications (for example, in Quirk et al. 1985: 1566-1567; Štekauer 1996: 94). The existence of a stress-affecting overt affix that derives toponyms (-iye) could be taken as evidence that toponyms conforming to Sezer stress may involve a similar, stressaffecting zero affix.

${ }^{23}$ As a reviewer points out, this implies that toponyms that do not derive from Turkish words, such as Án.ka.ra or Is.tán.bul, should be taken to involve the zero affix as well since they also bear Sezer stress systematically, which is unsatisfactory in terms of descriptive economy. However, the zero affix that is assumed here is based on the proportional opposition that it forms with overt toponym-forming affixes. The assignment of Sezer stress is also taken to be secondary, that is, the effect of a general phonological process on a domain created with a zero 
affix. A comparison can be made with a group of nouns that are converted from verbs in English (cf. Kiparsky 1982; Bermúdez-Otero 2012: 72-73): for instance, tórment ${ }^{\mathrm{N}}$, converted from tormént ${ }^{\mathrm{V}}$, adopts the default stress of simple noun stems with a final VCC rhyme: próvince, párent, vórtex. However, it is unintuitive to postulate that the words próvince, párent, vórtex also involve conversion, or that the category change in tormént ${ }^{\mathrm{V}} \rightarrow$ tórment $^{\mathrm{N}}$ is due to a suprasegmental element. By analogy, there seems to be no reason to assume that all members of the set of toponyms are subject to conversion.

${ }^{24}$ This also explains why pronouns are exempt from word-formation: they do not have a persistent referent. However, see Harris (2006) for an exceptional case in Georgian. 